\title{
Molecular and serological detection of tick-borne pathogens in dogs from an area endemic for Leishmania infantum in Mato Grosso do Sul, Brazil
}

\author{
Detecção sorológica e molecular de patógenos transmitidos por carrapatos em cães de uma área \\ endểmica para Leishmania infantum do estado do Mato Grosso do Sul \\ Keyla Carstens Marques de Sousa ${ }^{1}$; Marcos Rogério André1; Heitor Miraglia Herrera²; Gisele Braziliano de Andrade²; \\ Marcia Mariza Gomes Jusi ${ }^{1}$; Luciana Ladislau dos Santos ${ }^{2}$; Wanessa Teixeira Gomes Barreto ${ }^{2}$; \\ Rosangela Zacarias Machado'; Gilson Pereira de Oliveira ${ }^{1 *}$
}

\begin{abstract}
${ }^{1}$ Faculdade de Ciências Agrárias e Veterinárias - FCAV, Universidade Estadual Paulista - Unesp, Jaboticabal, SP, Brasil
${ }^{2}$ Universidade Católica Dom Bosco - UCDB, Campo Grande, MS, Brasil
\end{abstract}

Received May 14, 2013

Accepted October 28, 2013

\begin{abstract}
Tick-borne pathogens affect a wide range of vertebrate hosts. To identify tick-borne pathogens among dogs from Campo Grande, MS, Brazil testing seropositive for Leishmania infantum (syn. L. chagasi), a serological and molecular study was conducted to detect Ehrlichia canis, Anaplasma platys and Babesia vogeli in 60 serum and spleen samples. A confirmatory diagnosis of $L$. infantum based on serological and molecular assays was also performed, as was sequence alignment and phylogenetic analysis to assess the identity of the parasite species infecting these animals. IgG antibodies to Ehrlichia spp., B. vogeli and L. infantum were found, respectively, in $39(65 \%), 49(81.6 \%)$ and $60(100 \%)$ of the sampled dogs. Twenty-seven (45\%), fifty-four (90\%), fifty-three (88.3\%), two (3.3\%) and one (1.6\%) dog were positive, respectively, for E. canis, Leishmania spp., Leishmania donovani complex, Babesia sp. and Anaplasma sp. in PCR assays. After sequencing, the amplicons showed $99 \%$ of identity with E. canis, B. vogeli, A. platys and Leishmania chagasi isolates. The findings of this study indicate that $L$. infantum-seropositive dogs from Campo Grande are exposed to multiple tick-borne pathogens, which should therefore be included in the differential diagnosis of dogs with clinical suspicion of leishmaniasis.
\end{abstract}

Keywords: Ehrlichia canis, Babesia vogeli, Anaplasma platys, Leishmania infantum, dogs, co-infection.

\section{Resumo}

Patógenos transmitidos por carrapatos atingem uma variedade de hospedeiros vertebrados. Para identificar os agentes patogênicos transmitidos por carrapatos entre cães soropositivos para Leishmania infantum no município Campo Grande-MS, foi realizado um estudo sorológico e molecular para a detecção de Ehrlichia canis, Anaplasma platys e Babesia vogeli em 60 amostras de soro e baço, respectivamente. Adicionalmente, foi realizado o diagnóstico confirmatório de L. infantum por meio de técnicas sorológicas e moleculares. Também foi realizado o alinhamento e análise filogenética das sequências para indicar a identidade das espécies de parasitas que infectam esses animais. Anticorpos IgG anti-Ehrlichia spp., anti-B. vogeli e anti-L. infantum foram detectados em 39 (65\%), $49(81,6 \%)$ e $60(100 \%)$ dos cães amostrados, respectivamente. Vinte e sete (45\%), cinquenta e quatro (90\%), cinquenta e três (88,3\%), dois $(3,3 \%)$ e um $(1,6 \%)$ cães mostraram-se positivos na PCR para E. canis, Leishmania spp., Leishmania donovani complex, Babesia sp. e Anaplasma sp., respectivamente. Após o seqüenciamento, os amplicons mostraram 99\% de similaridade com isolados de E. canis, B. vogeli e A. platys e Leishmania chagasi. Os resultados deste estudo indicaram que os cáes soropositivos para $L$. infantum de Campo Grande, MS, são expostos a vários agentes transmitidos por carrapatos, e, portanto, devem ser incluídos no diagnóstico diferencial em cáes com suspeita clínica de leishmaniose.

Palavras-chave: Ehrlichia canis, Babesia vogeli, Anaplasma platys, Leishmania infantum, cáes, co-infecção.

\footnotetext{
${ }^{*}$ Corresponding author: Gilson Pereira de Oliveira

Faculdade de Ciências Agrárias e Veterinárias Júlio de Mesquita Filho,

Universidade Estadual Paulista - UNESP, Campus de Jaboticabal, Via de

Acesso Prof. Paulo Donato Castellane, s/n, Zona Rural, CEP 14884-900,

Jaboticabal, SP, Brasil

e-mail: gilsongpod@fcav.unesp.br
} 


\section{Introduction}

Tick-borne pathogens are emerging agents responsible for diseases in both humans and animals worldwide (SHAW et al., 2001). Ehrlichiosis, anaplasmosis and babesiosis are tick-borne diseases of worldwide occurrence in dogs, whose main vector is the brown dog tick, Rhipicephalus sanguineus (DAGNONE et al., 2003; NAKAGHI et al., 2008; OLIVEIRA et al., 2008). Dogs can be infected by several agents of the Anaplasmataceae family (DUMLER et al., 2001), such as Ehrlichia canis, Ehrlichia ewingii, Ehrlichia chaffeensis, Anaplasma platys, Anaplasma phagocytophilum, Neorickettsia risticii (INOKUMA et al., 2001) and $N$. helminthoeca (HEADLEY et al., 2006).

Ehrlichia canis is a common pathogen among domestic dogs in Brazil, and is considered primarily responsible for canine monocytic ehrlichiosis (NAKAGHI et al., 2008; DAGNONE et al., 2009). Clinical manifestations of the disease include fever, weight loss, anorexia, bleeding disorders and lymphadenopathy (CASTRO et al., 2004; NAKAGHI et al., 2008). Anaplasma platys, a bacterium that parasitizes platelets, causing canine cyclic thrombocytopenia (COHN, 2003), has also been reported in dogs in Brazil (DAGNONE et al., 2009). Furthermore, $A$. phagocytophilum also has been detected molecularly in dogs in the state of Rio de Janeiro, Brazil (SANTOS et al., 2011). Although dogs infected with $A$. platys and $A$. phagocytophilum usually present mild symptoms or are asymptomatic (HARRUS et al., 1997; KOHN et al., 2008; RAR; GOLOVLJOVA, 2011), some cases may be serious or fatal, particularly when co-infections are involved (DANTAS-TORRES, 2008). The confirmation of the occurrence of E. ewingii (OLIVEIRA et al., 2009) and A. phagocytophilum (SANTOS et al., 2011) in dogs from Minas Gerais and Rio de Janeiro, respectively, showed that other Anaplasmataceae agents circulate among dogs in Brazil, although the vector tick species involved in these transmission routes remains unknown.

Babesiosis, which is caused by intraerythrocytic protozoa of the genus Babesia sp., is an emerging disease transmitted to humans and animals by ticks (IRWIN, 2009). In Brazil, apart from a single report of $B$. gibsoni in a dog in the state of Paraná (TRAPP et al., 2006), dogs are more often parasitized by B. vogeli (PASSOS et al., 2005; FURUTA et al., 2009). Clinical manifestations of canine babesiosis are characterized by fever, lethargy, anorexia, jaundice, pale mucous membranes, splenomegaly, and weight loss. The prognosis for diseases caused by piroplasm species is usually good, except when the disease is caused by B. rossi and B. gibsoni (IRWIN, 2009; SOLANO-GALLEGO; BANETH, 2011).

Visceral leishmaniasis (VL), an infectious disease that affects both humans and animals, is caused by protozoan parasites of the genus Leishmania, such as Leishmania (Leishmania) donovani and Leishmania (Leishmania) infantum. The latter is endemic in the New World in regions extending from the southern United States to northern Argentina, including Brazil (KUHLS et al., 2011). The diagnosis of VL has proved to be problematic, mainly because of the wide variety of non-specific clinical symptoms, including a broad spectrum of presentations (BLAVIER et al., 2001). The immunosuppression observed in VL may promote the occurrence of co-infections with other agents such as Ehrlichia,
Babesia, Dirofilaria, Toxoplasma and Neospora in endemic regions (FEITOSA et al., 2000; PAULAN et al., 2013). On the other hand, a primary infection with tick-borne agents is likely to be a contributing factor to the establishment of canine VL, as was shown for ehrlichiosis in a longitudinal study of naturally exposed naïve dogs (MEKUZAS et al., 2009). The present study aimed to verify the occurrence of $E$. canis, $A$. platys and $B$. vogeli among $L$. infantum-seropositive dogs from Campo Grande in the Brazilian state of Mato Grosso do Sul (MS), using serological and molecular techniques.

\section{Materials and Methods}

Between June 2011 and March 2012, serum and spleen samples were collected from $60 \mathrm{~L}$. infantum-seropositive dogs from the Center for Zoonosis Control (CZC) of Campo Grande, Mato Grosso do Sul and subjected to an enzyme-linked immunosorbent assay (ELISA). Blood samples for the serological tests were drawn from each dog by cephalic venipuncture and stored without anticoagulant (EDTA). During necropsy, fragments of spleen were collected aseptically and stored in absolute ethanol for DNA extraction. Additionally, serological and molecular assays were performed for a confirmatory diagnosis of L. infantum.

A Leishmania sp. strain isolated in Araçatuba, São Paulo, Brazil, characterized as donovani complex, probably L. infantum, using molecular techniques described by Cortes et al., (2004), was used in this study. The parasites were maintained on RPMI-1640 medium (Sigma-Aldrich, St. Louis, USA) supplemented with $10 \%$ heat-inactivated fetal bovine serum (FBS; Gibco, Canyon City, USA) at $25^{\circ} \mathrm{C}$ and were used to prepare the crude antigens for IFAT and ELISA.

The ELISA method employed here was described in detail by Oliveira et al. (2008). Briefly, $100 \mathrm{~mL}$ of crude Leishmania sp. antigen diluted in $0.05 \mathrm{M}$ sodium carbonate-bicarbonate buffer ( $\mathrm{pH}$ 9.6) was added to each well on ELISA plates (Nunclon TM surface; Nunc, Denmark) and $5 \mathrm{mg} \mathrm{mL}$ protein concentration was used. After overnight incubation at $4{ }^{\circ} \mathrm{C}$, the plates were washed three times with $0.05 \%$ PBS Tween-20. The plates were blocked with $200 \mathrm{~mL}$ containing $6 \%$ skim milk for 2 hours at $37^{\circ} \mathrm{C}$ to reduce nonspecific binding. The blocking agent was removed, and individual dog serum diluted (1:400) in PBS Tween-20 with $5 \%$ skim milk added to each well, followed by incubation for 90 minutes at $37^{\circ} \mathrm{C}$ and washing as described above. One hundred $\mathrm{mL}$ of alkaline phosphatase conjugated anti-dog IgG (Sigma-Aldrich, St. Louis, USA) diluted at 1: 4.000 in PBS Tween-20 with 5\% normal rabbit serum was added to each well, followed by incubation for 90 minutes at $37^{\circ} \mathrm{C}$. The plates were washed and the substrate ( $\mathrm{p}$-nitrophenyl phosphate) diluted in diethanolamine buffer, $\mathrm{pH}$ 9.8, was added. Absorbance at $405 \mathrm{~nm}$ was read after 45 minutes of incubation at room temperature, using an ELISA reader (Dynex Technologies, USA). The discriminating absorbance value (cut-off) was determined as being 2.5 times the mean absorbance value of the negative control.

Ehrlichia spp. antigen was obtained from E. canis (Jaboticabal strain)-infected DH82 cells maintained in culture in the Immunoparasitology Laboratory of UNESP at Jaboticabal, São 
Paulo (AGUIAR et al., 2007). Babesia spp. antigen was prepared by intravenous inoculation of $B$. vogeli (Jaboticabal strain) into a splenectomized three month-old dog negative for hemoparasites by PCR and serology (FURUTA et al., 2009). Giemsa-stained blood smears were examined microscopically twice daily day for the presence of parasites. After peak parasitemia was observed on the fifth day after inoculation, infected blood was collected with Alsever's solution (113.7 mM glucose, $27.2 \mathrm{mM}$ sodium citrate, $71.8 \mathrm{mM}$ sodium chloride).

Slides containing air-dried fixed $B$. vogeli trophozoiteinfected blood, E. canis-infected DH82 cells and Leishmania sp. promastigotes were tested by IFAT (Indirect Fluorescent Antibody Test), as described previously (FURUTA et al., 2009; NAKAGHI et al., 2008; OLIVEIRA et al., 2008). Antigen slides were removed from storage $\left(-20^{\circ} \mathrm{C}\right)$ and allowed to thaw at room temperature for $30 \mathrm{~min}$. Ten microliters of twofold dilutions of sera (cut-off of 1:64 for Ehrlichia spp., 1:40 for B. vogeli and 1:40 for $L$. infantum) were placed in wells on antigen slides. Canine sera known to be positive for E. canis, B. vogeli and L. infantum were obtained from symptomatic dogs with ehrlichiosis, babesiosis and leishmaniasis treated in the Governador Laudo Natel Veterinary Hospital of UNESP at Jaboticabal, SP, Brazil, and used as positive control. Negative control serum samples were obtained from dogs (unexposed to these agents, according to negative PCR and IFAT results) that were kept at the kennel of the Department of Veterinary Pathology of UNESP at Jaboticabal. Slides were incubated at $37^{\circ} \mathrm{C}$ in a moist chamber for $45 \mathrm{~min}$, washed 3 times in PBS ( $\mathrm{pH} 7.2$ ) for $5 \mathrm{~min}$, and air dried at room temperature. FITC-labeled anti-dog IgG conjugate (Sigma-Aldrich ${ }^{\circledR}$, St. Louis, MO, USA) was diluted according to the manufacturer's instructions (dilution of 1:32) and added to each well. These slides were incubated again at $37^{\circ} \mathrm{C}$, washed 3 times in PBS, then in distilled water, and air dried at room temperature. Next, coverslips were placed on the slides, which were examined under a fluorescence microscope.

DNA was extracted from spleen fragments using the QIAamp DNA Blood and Tissue Mini Kit (QIAGEN, Valencia, California, USA) according to the manufacturer's instructions. Each sample of extracted DNA was used as a template in $25 \mu \mathrm{L}$ of reaction mixture containing 10x PCR buffer, $1.0 \mathrm{mM} \mathrm{MgCl}_{2}$, $0.2 \mathrm{mM}$ deoxynucleoside triphosphate (dNTPs) mixture, and 1.5 U Taq DNA Polymerase (Invitrogen, Carlsbad, California, USA) with $0.5 \mu \mathrm{M}$ of genus specific primers for Ehrlichia spp. (16S rRNA gene) (MURPHY et al., 1998), Anaplasma spp. (16S rRNA gene) (MASSUNG et al., 1998), Babesia spp. (18S rRNA gene) (CARRET et al., 1999), Leishmania spp. (kinetoplast DNA) (MICHALSKY et al., 2002) and L. donovani complex (CORTES et al., 2004) (Table 1). Positive controls of $E$. canis and B. vogeli DNA samples were obtained from dogs infected experimentally with Jaboticabal strains of $E$. canis (CASTRO et al., 2004) and B. vogeli (FURUTA et al., 2009), respectively. $A$. platys DNA positive control was obtained from a dog from Campo Grande, MS naturally infected with $A$. platys (DAGNONE et al., 2009). L. infantum DNA positive control was obtained from parasites maintained in culture. Ultrapure sterile water was used as negative control. To prevent PCR contamination, the DNA extraction, reaction setup, PCR amplification and electrophoresis were performed in separate rooms. The reaction products were purified using a Silica Bead DNA Gel Extraction

Table 1. Description of primers, PCR product size and references used in PCR assays for E. canis, Anaplasma spp., Babesia spp., Leishmania spp. and L. donovani complex.

\begin{tabular}{|c|c|c|c|}
\hline Agent and Primers & Oligonucleotide Sequence & Product PCR Size & References \\
\hline \multicolumn{4}{|l|}{ Ehrlichia spp. } \\
\hline$-\mathrm{ECC}$ & 5’- GAACGAACGCTGGCGGCAAGC-3' & 478 & MURPHY et al., 1998 \\
\hline$-\mathrm{ECB}$ & 5'- CGTATTACCGCGGCTGCTGGCA -3' & & \\
\hline \multicolumn{4}{|l|}{ Nested E. canis } \\
\hline$-\mathrm{ECAN}-5$ & 5’-CAA TTATTTATAGCCTCTGGCTATAGGA-3' & 358 & MURPHY et al., 1998 \\
\hline$-\mathrm{HE} 3$ & 5'-TATAGGTACCGTCATTATCTTCCCTAT-3' & & \\
\hline \multicolumn{4}{|l|}{ Anaplasma spp. } \\
\hline$-g E 3 a$ & 5'-CACATGCAAGTCGAACGGATTATTC-3' & 932 & MASSUNG et al., 1998 \\
\hline$-\mathrm{gE} 10 \mathrm{R}$ & 5'- TTCCGTTAAGAAGGATCTAATCTCC'-3' & & \\
\hline \multicolumn{4}{|c|}{ 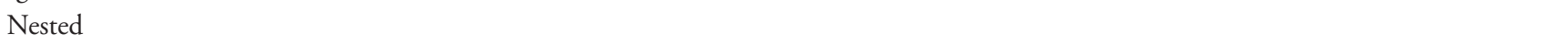 } \\
\hline \multicolumn{4}{|l|}{ Anaplasma spp. } \\
\hline$-g E 2$ & 5'- GGCAGTATTAAAAGCAGCTCCAGG-3' & 546 & MASSUNG et al., 1998 \\
\hline$-g E 9 f$ & 5'-AACGGATTATTCTTTATAGCTTGCT-3' & & \\
\hline \multicolumn{4}{|l|}{ Babesia spp. } \\
\hline -Piro A & 5'-AATACCCAATCCTGACACAGGG-3' & 400 & CARRET et al., 1999 \\
\hline -Piro B & 5'-TTAAATACGAATGCCCCCAAC-3' & & \\
\hline \multicolumn{4}{|l|}{ Leishmania spp. } \\
\hline$-\mathrm{L} 1$ & 5'-GGGGAGGGGCGTTCTGCGAA-3' & 120 & MICHALSKY et al., 2002 \\
\hline$-\mathrm{L} 2$ & 5'-GGCCCACTATATTACACCAACCCC-3' & & \\
\hline \multicolumn{4}{|l|}{ L. donovani complex } \\
\hline$-\mathrm{MC1}$ & 5'-GTTAGCCGATGGTGGTCTTG-3' & 447 & CORTES et al., 2004 \\
\hline$-\mathrm{MC} 2$ & 5'-CACCCATTT TTCCGA TTT TG-3' & & \\
\hline
\end{tabular}


Kit (Fermentas ${ }^{\circledR}$, São Paulo, SP, Brazil). Purified amplified DNA fragments were subjected in-house to sequence confirmation in an automatic sequencer (ABI Prism 310 Genetic Analyzer - Applied Biosystem/ Perkin Elmer) and used for subsequent phylogenetic analysis. Phylogenetic reconstructions were based on DNA sequence alignment of positive samples. Consensus sequences were obtained by analyzing the sense and antisense sequences using the CAP3 program (http://mobyle.pasteur.fr/cgibin/MobylePortal/portal.py). Comparisons were made with sequences deposited in GenBank using the basic local alignment search tool (BLAST).

\section{Results}

IgG antibodies to Ehrlichia spp., B. vogeli and L. infantum were found, respectively, in 39 (65\%), 49 (81.6\%) and 60 (100\%) sampled dogs. IFAT titers ranged from 40 to 5120 for B. vogeli, 64 to 2048 for Ehrlichia spp. and 40 to 20480 for L. infantum. Thirty-four dogs (56.6\%) showed antibodies to Ehrlichia spp., B. vogeli, and L. infantum; 6 (10\%) dogs were seronegative for Ehrlichia spp. and B. vogeli, but seropositive for L. infantum. Five (8.3\%) dogs were seropositive only for Ehrlichia spp. and L. infantum; 15 (25\%) were seropositive only for B. vogeli and L. infantum, and six (10\%) dogs were only seropositive for L. infantum (Table 2).

Twenty-seven (45\%) dogs were positive for E. canis nPCR, 54 (90\%) for Leishmania spp. PCR, 53 (88.3\%) for L. donovani complex PCR, two (3.3\%) for Babesia spp. PCR and only one dog (1.6\%) for Anaplasma spp. nPCR. All 27 E. canis-nPCR positive dogs showed antibodies to the agent; 12 (30.7\%) out of 39 Ehrlichia spp -seropositive dogs did not test positive in the nPCR assay. Twenty-one (35\%) out of 60 sampled dogs were negative for both Ehrlichia spp -IFAT and nPCR. Twenty-three (38.3\%) dogs were positive for both E. canis and Leishmania spp. PCR assays, and 22 (36.6\%) for E. canis and L. donovani complex PCR assays (Table 2).

Only one dog was positive for both $B$. vogeli-IFAT and PCR, showing a low titer (40) in IFAT. One dog was positive in PCR but negative in IFAT for B. vogeli. Forty-eight (80\%) dogs tested positive for $B$. vogeli only in IFAT. Ten (16.6\%) dogs were negative for both $B$. vogeli-IFAT and PCR. One $\operatorname{dog}(1.6 \%)$ was positive for E. canis nPCR and Babesia spp. PCR, respectively, and one animal (1.6\%) tested positive in the Leishmania spp., L. donovani complex and Babesia spp. PCR assays. One (1.6\%) dog tested positive in all Anaplasma spp. nPCR, Leishmania spp. and $L$. donovani complex PCR assays, and showed antibodies for both $B$. vogeli and $L$. infantum (Table 2 ).

Fifty-three dogs (88.3\%) tested positive in L. infantum IFAT and Leishmania spp. and L. donovani complex PCR assays. Only one dog was positive for Leishmania spp. PCR and negative for L. donovani complex PCR. All 54 Leishmania-PCR positive dogs showed antibodies to this agent; $6(10 \%)$ and $7(11.6 \%)$ out of 60 L. infantum-seropositive dogs did not test positive in Leishmania spp. and L. donovani complex PCR assays, respectively (Table 2).

After sequencing, amplicons obtained in the E. canis nPCR (358 pb) showed $99 \%$ of identity with sequences of $E$. canis found in dogs from the Philippines (JX893523), Japan (AB723712) and Taiwan (GU810149) by BLAST analysis. An amplicon obtained after Anaplasma spp. nPCR (546 pb) showed 99\% of identity with sequences of $A$. platys found in dogs from the Philippines (JQ894779), Croatia (JQ396431) and Malaysia (JF683610). Amplicons obtained in Babesia spp. PCR (400 pb) showed 99\% of identity with sequences of $B$. vogeli found in dogs from Colombia (JN368081), China (HM590440) and Venezuela (DQ297390). Amplicons obtained in L. donovani complex PCR (447pb) showed 99\% of identity with the complete sequence of Leishmania infantum (syn. L. chagasi) (AF169138, AF103741, AF169139). Ehrlichia canis and $A$. platys strain Campo Grande-MS 16S rRNA partial sequence, $B$. vogeli strain Campo Grande-MS 18S rRNA partial sequences, and L. infantum strain Campo Grande-MS kinetoplast DNA partial sequence were deposited in GenBank database under access numbers KC989958, KC989957, KC989959 and KF695386 respectively.

\section{Discussion}

This study demonstrated the occurrence of E. canis, A. platys and $B$. vogeli in L. infantum-seropositive dogs from Campo Grande, MS, by molecular and serological techniques. L. infantum IFAT confirmed the results of the ELISA test conducted at the CZC. On the other hand, only $54(90 \%)$ of the animals

Table 2. Results of serology for E. canis, B. vogeli and L. infantum and PCR for Anaplasma spp, Babesia spp, E. canis, Leishmania spp. and L. donovani complex in 60 dogs from Campo Grande, MS, Brazil.

\begin{tabular}{|c|c|c|c|c|c|c|c|c|c|c|}
\hline \multirow{3}{*}{ Serology } & \multicolumn{10}{|c|}{ PCR } \\
\hline & \multicolumn{2}{|c|}{ Babesia spp. } & \multicolumn{2}{|c|}{ E. canis } & \multicolumn{2}{|c|}{ Anaplasma spp. } & \multicolumn{2}{|c|}{ Leishmania spp.. } & \multicolumn{2}{|c|}{ L. donovani complex } \\
\hline & + & - & + & - & + & - & + & - & + & - \\
\hline Seropositive to B. vogeli $(\mathrm{n}=49)$ & 1 & 48 & 24 & 25 & 1 & 48 & 45 & 4 & 44 & 5 \\
\hline Seronegative to $B$. vogeli $(\mathrm{n}=11)$ & 1 & 10 & 3 & 8 & 0 & 11 & 9 & 2 & 9 & 2 \\
\hline Seropositive to E.canis $(\mathrm{n}=39)$ & 1 & 38 & 27 & 12 & 0 & 39 & 34 & 20 & 33 & 6 \\
\hline Seronegative to E.canis $(\mathrm{n}=21)$ & 1 & 20 & 0 & 21 & 0 & 21 & 5 & 1 & 20 & 1 \\
\hline Seropositive to $L$. infantum $(\mathrm{n}=60)$ & 2 & 58 & 27 & 33 & 1 & 59 & 54 & 6 & 53 & 7 \\
\hline Seronegative to $L$. infantum $(\mathrm{n}=0)$ & 0 & 0 & 0 & 0 & 0 & 0 & 0 & 0 & 0 & 0 \\
\hline Total $(\mathrm{n}=60)$ & 2 & 58 & 27 & 33 & 1 & 59 & 54 & 6 & 53 & 7 \\
\hline
\end{tabular}


tested positive in the Leishmania spp. PCR assay and 53 in the L. donovani complex PCR assay. Although Brazil's Ministry of Health recommends serological assays for the diagnosis of $L$. infantum (BRASIL, 2003), cross-reactivity between Trypanosoma cruzi and Leishmania braziliensis-infected patients is well documented in the serodiagnosis of leishmaniasis (VEXENAT et al., 1996; LUCIANO et al., 2009). In our study, cross-reactivity between dog serum samples positive to T. cruzi and L. braziliensis could not be discarded, since the occurrence of T. cruzi and L. braziliensis among dogs is documented in the state of Mato Grosso do Sul (POMPILIO et al., 2005; SAVANI et al., 2009; SOUZA et al., 2009; CORVALAN et al., 2011). One dog that tested positive in the Leishmania spp. PCR assay but negative in the PCR assay for $L$. donovani complex could be infected by other Leishmania spp. species, i.e., L. braziliensis or L. amazonensis, which have been reported previously in the state of Mato Grosso do Sul (DORVAL et al., 2006; CORVALAN et al., 2011).

There are a few reports about the occurrence of Babesia spp. in dogs from Campo Grande, MS, which are based only on the observation of piroplasms in blood smears (SALGADO, 2006). Serology is a useful tool for the diagnosis of reservoir hosts for Babesia spp., because the parasitemia in dogs naturally infected with $B$. vogeli is usually low (FURUTA et al., 2009). Although the molecular detection of $B$. vogeli in the present study was low (3.3\%), the overall seroprevalence was $81.6 \%$, suggesting a previous exposure to this agent. PCR is considered a highly sensitive and specific technique, but its sensitivity is low when samples are collected from naturally asymptomatic Babesia-infected dogs in the chronic phase of the disease (BOOZER; MACINTIRE, 2003), when low fluctuations in parasitemia are observed (IRWIN, 2009). In our study, the presence of dogs seropositive to $B$. vogeli showing negative results for Babesia spp. PCR suggests the occurrence of subclinical or chronic phase of the disease in these animals. On the other hand, these same dogs could have been exposed to $B$. vogeli previously, maintaining detectable antibody levels. After sequencing, the Babesia spp. found in dogs from Campo Grande showed 99\% of identity with B. vogeli, which has already been found in dogs in the Brazilian states of Minas Gerais (PASSOS et al., 2005; COSTA-JÚNIOR et al., 2009), Pernambuco (RAMOS et al., 2010), Goiás (DUARTE et al., 2011) and Mato Grosso (SPOLIDORIO et al., 2011). Serological surveys revealed that the prevalence of antibodies to $B$. vogeli in dogs in Brazil ranged from 28.7\% (COSTA-JÚNIOR et al., 2009) to 46.4\% (VIEIRA et al., 2013). Also, B. gibsoni has been detected in dogs in the state of Paraná (TRAPP et al., 2006).

Although the presence of $E$. canis DNA has already been detected in dogs in Campo Grande (DAGNONE et al., 2009), the present work showed a high occurrence of seropositive (65\%) and PCR-positive animals (45\%), indicating that this agent is widespread among dogs in this city. Thirty percent of dogs seropositive to $E$. canis were negative in the PCR assay, suggesting that these animals could be in the subclinical or chronic phase of the disease or that they were previously exposed to E. canis. Ehrlichia canis is a widespread tick-borne agent of dogs in Brazil and has been molecularly detected in several states, e.g., São Paulo (NAKAGHI et al., 2008; DAGNONE et al., 2009), Rio de Janeiro (MACIEIRA et al., 2005), Paraná (DAGNONE et al.,
2003), Bahia (CARVALHO et al., 2008), Mato Grosso do Sul (DAGNONE et al., 2009) and Paraíba (TANIKAWA et al., 2013). Antibodies to $E$. canis have also been detected in almost all Brazilian states, with the prevalence of exposure in dogs ranging from $4.8 \%$ (SAITO et al., 2008) to 73\% (NAKAGHI et al., 2008). Although $E$. canis DNA has been detected in humans in Venezuela (PEREZ et al., 2006; UNVER et al., 2001), the importance of the parasite as a zoonotic agent remains unknown.

Anaplasma platys has been molecularly detected in dogs in the states of from Mato Grosso do Sul (DAGNONE et al., 2009), São Paulo (DAGNONE et al., 2009), Pernambuco (RAMOS et al., 2010) and Paraná (SILVA et al., 2012). The percentage of $A$. platys positive samples by PCR assay in our study (1.6\%) was lower than that found by Dagnone et al. (2009) (45\%) in dogs of Campo Grande, MS, probably because all the dogs sampled in the earlier study showed clinical signs of tick-borne diseases and the presence of intracytoplasmic inclusion bodies in leucocytes and platelets. PCR has shown higher sensitivity in dogs sampled in the acute phase of the disease caused by $A$. platys (DAGNONE et al., 2009).

The occurrence of co-positivity in PCR for B. vogeli and $E$. canis in one dog, and the evidence of exposure to both agents (seropositivity for E. canis and B. vogeli in $56.6 \%$ of the sampled dogs) suggest the transmission of both agents by the same tick vector. Cases of co-infection by $B$. vogeli, E. canis and $A$. platys are frequently found due to the common tick vector of Brazilian dogs, $R$. sanguineus (DAGNONE et al., 2003; NAKAGHI et al., 2008; OLIVEIRA et al., 2008), which can transmit all three agents (DANTAS-TORRES, 2008). Moreover, the environmental conditions may have contributed to the animals' exposure to the agents, since they lived in the same location (CZC). Studies are much needed on the interaction of tick-borne agents and Leishmania parasites in the establishment and course of the disease.

In conclusion, this paper described a study of the molecular detection of E. canis, A. platys and B. vogeli in L. infantumseropositive dogs from Campo Grande, MS. These pathogens should be included in the differential diagnosis of dogs with compatible clinical signs and hematological abnormalities suggestive of tickborne diseases in Campo Grande, MS.

\section{References}

Aguiar DM, Saito TB, Hagiwara MK, Machado RZ, Labruna MB. Serological diagnosis of canine monocytic ehrlichiosis with Brazilian antigen of Ehrlichia canis. Cienc Rural 2007; 37(3): 796-802. http:// dx.doi.org/10.1590/S0103-84782007000300030

Blavier A, Keroack S, Denerolle P, Goy-Thollot I, Chabanne L, Cadoré JL, et al. Atypical forms of canine leishmaniosis. Vet J2001; 162(2): 108120. PMid:11531395. http://dx.doi.org/10.1053/tvjl.2000.0556

Boozer AL, Macintire DK. Canine babesiosis. Vet Clin North Am Small Anim Pract 2003; 33(4): 885-904. http://dx.doi.org/10.1016/S01955616(03)00039-1

Brasil. Ministério da Saúde. Manual de vigilância e controle da Leishmaniose Visceral: normas e manuais técnicos. Brasília: Ministério da Saúde; 2003. 120 p.

Carvalho FS, Wenceslau AA, Carlos RS, Albuquerque GR. Epidemiological and molecular study of Ehrlichia canis in dogs in Bahia, Brazil. Genet Mol 
Res 2008; 7(3): 657-662. PMid:18752193. http://dx.doi.org/10.4238/ vol7-3gmr468

Carret C, Walas F, Carcy B, Grande N, Précigout E, Moubri K, et al. Babesia canis canis, Babesia canis vogeli, Babesia canis rossi: differentiation of the three subspecies by a restriction fragment length polymorphism analysis on amplified small subunit ribosomal RNA genes. J Eukaryot Microbiol 1999; 46(3): 298-303. PMid:10377990. http://dx.doi. org/10.1111/j.1550-7408.1999.tb05128.x

Castro MB, Machado RZ, Aquino LP, Alessi AC, Costa MT. Experimental acute canine monocytic ehrlichiosis: clinicopathological and immunopathological findings. Vet Parasitol 2004; 119(1): 73-86. PMid:15036578. http://dx.doi.org/10.1016/j.vetpar.2003.10.012

Cohn LA. Ehrlichiosis and related infections. Vet Clin North Am Small Anim Pract 2003; 33(4): 863-884. http://dx.doi.org/10.1016/S01955616(03)00031-7

Cortes S, Rolão N, Ramada J, Campino L. PCR as a rapid and sensitive tool in the diagnosis of human and canine leishmaniasis using Leishmania donovani s.l. - specific kinetoplastid primers. Trans $R$ Soc Trop Med Hyg 2004; 98(1): 12-17. http://dx.doi.org/10.1016/S00359203(03)00002-6

Corvalan FH, Sampaio RNR, Brustoloni YM, Andreotti R, Lima MSC Jr. DNA identification of Leishmania (Viannia) braziliensis in human saliva from a patient with American cutaneous leishmaniasis. J Venom Anim Toxins incl Trop 2011; 17(1): 98-102. http://dx.doi.org/10.1590/ S1678-91992011000100013

Costa-Júnior LM, Ribeiro MF, Rembeck K, Rabelo EM, Zahler-Rinder M, Hirzmann J, et al. Canine babesiosis caused by Babesia canis vogeli in rural areas of the State of Minas Gerais, Brazil and factors associated with its seroprevalence. Res Vet Sci 2009; 86(2): 257-260. PMid:18723199. http://dx.doi.org/10.1016/j.rvsc.2008.07.002

Dagnone AS, de Morais HS, Vidotto MC, Jojima FS, Vidotto O. Ehrlichiosis in anemic, thrombocytopenic, or tick-infested dogs from a hospital population in South Brazil. Vet Parasitol 2003; 117(4): 285290. PMid:14637030. http://dx.doi.org/10.1016/j.vetpar.2003.10.001

Dagnone AS, Souza AI, André MR, Machado RZ. Molecular diagnosis of Anaplasmataceae organisms in dogs with clinical and microscopical signs of ehrlichiosis. Rev Bras Parasitol Vet 2009; 18(4): 20-25. PMid:20040204. http://dx.doi.org/10.4322/rbpv.01804004

Dantas-Torres F. Canine vector-borne diseases in Brazil. Parasit Vectors 2008; 1(1): 25. PMid:18691408 PMCid:PMC2533296. http:// dx.doi.org/10.1186/1756-3305-1-25

Dorval ME, Oshiro ET, Cupollilo E, Castro AC, Alves TP. Occurrence of American tegumentary leishmaniasis in the Mato Grosso do Sul State associated to the infection for Leishmania (Leishmania) amazonensis. Rev Soc Bras Med Trop 2006; 39(1): 43-46. PMid:16501765. http://dx.doi. org/10.1590/S0037-86822006000100008

Duarte SC, Parente JA, Pereira M, Soares CM, Linhares GF. Phylogenetic characterization of Babesia canis vogeli in dogs in the state of Goiás, Brazil. Rev Bras Parasitol Vet 2011; 20(4): 274-280. PMid:22166380. http:// dx.doi.org/10.1590/S1984-29612011000400004

Dumler JS, Barbet AF, Bekker CP, Dasch GA, Palmer GH, Ray SC, et al. Reorganization of genera in the families Rickettsiaceae and Anaplasmataceae in the order Rickettsiales: identification of some species of Ehrlichia with Anaplasma, Cowdria with Ehrlichia and Ehrlichia with Neorickettsia, descriptions of six new species combinations and designation of Ehrlichia equi and 'HGE a gent' as subjective synonyms of Ehrlichia phagocytophila. Int J Syst Evol Microbiol 2001; 51(6): 2145 2165. PMid:11760958. http://dx.doi.org/10.1099/00207713-51-6-2145

Feitosa MM, Ikeda FA, Luvizotto MCR, Perri SHV. Aspectos clínicos de cães com leishmaniose visceral no município de Araçatuba, São Paulo (Brasil). Clin Vet 2000; 28:36-44.

Furuta PI, Oliveira TMFS, Teixeira MCA, Rocha AG, Machado RZ, Tinucci-Costa M. Comparison between a soluble antigen-based ELISA and IFAT in detecting antibodies against Babesia canis in dogs. Rev Bras Parasitol Vet 2009; 18(3): 41-45. PMid:19772774. http://dx.doi. org/10.4322/rbpv.01803007

Harrus S, Aroch I, Lavy E, Bark H. Clinical manifestations of infectious canine cyclic thrombocytopenia. Vet Rec 1997; 141(10): 247-250. PMid:9308149. http://dx.doi.org/10.1136/vr.141.10.247

Headley SA, Scorpio D, Barat N, Vidotto O, Dumler JS. Neorickettsia helminthoeca in dog, Brazil. Emerg Infect Dis 2006; 12(8): 1303-1305. PMid:16972361 PMCid:PMC3291224. http://dx.doi.org/10.3201/ eid1708.060130

Inokuma H, Parola P, Raoult D, Brouqui P. Molecular survey of Ehrlichia infection in ticks from animals in Yamaguchi Prefecture, Japan. Vet Parasitol 2001; 99(4): 335-339. http://dx.doi.org/10.1016/S03044017(01)00470-8

Irwin PJ. Canine babesiosis: from molecular taxonomy to control. Parasit Vectors 2009; 2(1 Suppl): S4. PMid:19426443 PMCid:PMC2679396. http://dx.doi.org/10.1186/1756-3305-2-S1-S4

Kohn B, Galke D, Beelitz P, Pfister K. Clinical features of canine granulocytic anaplasmosis in 18 naturally infected dogs. J Vet Intern Med 2008; 22(6): 1289-1295. PMid:18783353. http://dx.doi. org/10.1111/j.1939-1676.2008.0180.x

Kuhls K, Alam MZ, Cupolillo E, Ferreira GE, Mauricio IL, Oddone R, et al. Comparative microsatellite typing of new world Leishmania infantum reveals low heterogeneity among populations and its recent old world origin. PLoS Negl Trop Dis 2011; 5(6): e1155. PMid:21666787 PMCid:PMC3110170. http://dx.doi.org/10.1371/ journal.pntd.0001155

Luciano RM, Lucheis SB, Troncarelli MZ, Luciano DM, Langoni H. Avaliação da reatividade cruzada entre antígenos de Leishmania spp e Trypanosoma cruzi na resposta sorológica de cáes pela técnica de imunofluorescência indireta (RIFI). Braz. J Vet Res Anim Sci 2009; 46(3): 181-187.

Macieira DB, Messick JB, Cerqueira AM, Freire IM, Linhares GF, Almeida NK, et al. Prevalence of Ehrlichia canis infection in thrombocytopenic dogs from Rio de Janeiro, Brazil. Vet Clin Pathol 2005; 34(1): 44-48. http://dx.doi.org/10.1111/j.1939-165X.2005.tb00008.x

Massung RF, Slater K, Owens JH, Nicholson WL, Mather TN, Solberg VB, et al. Nested PCR assay for detection of Granulocytic Ehrlichiae. J Clin Microbiol 1998; 36(4): 1090-1095. PMid:9542943 PMCid:PMC104695.

Mekuzas Y, Gradoni L, Oliva G, Foglia Manzillo V, Baneth G. Ehrlichia canis and Leishmania infantum co-infection: a 3-year longitudinal study in naturally exposed dogs. Clin Microbiol Infect 2009; 15(2 Suppl): 30-31. PMid:19416288. http://dx.doi.org/10.1111/j.1469-0691.2008.02150.x

Michalsky EM, Fortes-Dias CL, Pimenta PF, Secundino NF, Dias ES. Assessment of PCR in the detection of Leishmania spp. in experimentally infected individual phlebotomine sandflies (Diptera: Psychodidae: Phlebotominae). Rev Inst Med Trop 2002; 44(5): 255-259. http://dx.doi. org/10.1590/S0036-46652002000500004 
Murphy GL, Ewing SA, Whitworth LC, Fox JC, Kocan AA. A molecular and serological survey of Ehrlichia canis, E. chaffeensis, and E. ewingii in dogs and ticks from Oklahoma. Vet Parasitol 1998; 79(4): 325-339. http://dx.doi.org/10.1016/S0304-4017(98)00179-4

Nakaghi ACH, Machado RZ, Tinucci-Costa M, André MR, Baldani CD. Canine ehrlichiosis: clinical, hematological, serological and molecular aspects. Cienc Rural 2008; 38(3): 766-770. http://dx.doi.org/10.1590/ S0103-84782008000300027

Oliveira LS, Oliveira KA, Mourão LC, Pescatore AM, Almeida MR, Conceição LG, et al. First report of Ehrlichia ewingii detected by molecular investigation in dogs from Brazil. Clin Microbiol Infect 2009; 15(2 Suppl): 55-56. PMid:19416280. http://dx.doi. org/10.1111/j.1469-0691.2008.02635.x

Oliveira TM, Furuta PI, de Carvalho D, Machado RZ. A study of crossreactivity in serum samples from dogs positive for Leishmania sp., Babesia canis and Ehrlichia canis in enzyme-linked immunosorbent assay and indirect fluorescent antibody test. Rev Bras Parasitol Vet 2008;17(1): 7-11. PMid:18554433.

Passos LM, Geiger SM, Ribeiro MF, Pfister K, Zahler-Rinder M. First molecular detection of Babesia vogeli in dogs from Brazil. Vet Parasitol 2005; 127(1): 81-85. PMid:15619377. http://dx.doi. org/10.1016/j.vetpar.2004.07.028

Paulan SC, Lins AGS, Tenório MS, Silva DT, Pena HFJ, Machado RZ, et al. Seroprevalence rates of antibodies against Leishmania infantum and other protozoan and rickettsial parasites in dogs. Rev Bras Parasitol Vet 2013; 22(1): 162-166. http://dx.doi.org/10.1590/S198429612013000100031

Perez M, Bodor M, Zhang C, Xiong Q, Rikihisa Y. Human infection with Ehrlichia canis accompanied by clinical signs in Venezuela. Ann N Y Acad Sci 2006; 1078: 110-117. PMid:17114689. http://dx.doi. org/10.1196/annals.1374.016

Pompilio MA, Dorval ME, Cunha RV, Britto C, Borges-Pereira J. Epidemiological, clinical and parasitological aspects of Chagas' disease in Mato Grosso do Sul State. Rev Soc Bras Med Trop. 2005; 38(6): 473478. PMid:16410921. http://dx.doi.org/10.1590/S003786822005000600005

Ramos R, Ramos C, Araújo F, Oliveira R, Souza I, Pimentel D, et al. Molecular survey and genetic characterization of tick-borne pathogens in dogs in metropolitan Recife (north-eastern Brazil). Parasitol Res 2010; 107(5): 1115-1120. PMid:20680344. http://dx.doi. org/10.1007/s00436-010-1979-7

Rar V, Golovljova I. Anaplasma, Ehrlichia, and "Candidatus Neoehrlichia” bacteria: pathogenicity, biodiversity, and molecular genetic characteristics, a review. Infect Genet Evol 2011; 11(8): 1842-1861. PMid:21983560. http://dx.doi.org/10.1016/j.meegid.2011.09.019

Saito TB, Cunha-Filho NA, Pacheco RC, Ferreira F, Pappen FG, Farias NA, et al. Canine infection by Rickettsiae and Ehrlichiae in Southern Brazil. Am J Trop Med Hyg 2008; 79(1): 102-108. PMid:18606772.

Salgado FP. Identificação de hemoparasitos e carrapatos de cães procedentes do Centro de Controle de Zoonoses de Campo Grande, Estado do Mato Grosso do Sul, Brasil [Dissertação]. Campo Grande: Universidade Federal de Mato Grosso do Sul; 2006.
Santos HA, Pires MS, Vilela JAR, Santos TM, Faccini JLH, Baldani $\mathrm{CD}$, et al. Detection of Anaplasma phagocytophilum in Brazilian dogs by real-time polymerase chain reaction. J Vet Diagn Invest 2011; 23(4): 770774. PMid:21908321. http://dx.doi.org/10.1177/1040638711406974

Savani ES, Nunes VL, Galati EA, Castilho TM, Zampieri RA, Floeter-Winter LM. The finding of Lutzomyia almerioi and Lutzomyia longipalpis naturally infected by Leishmania spp. in a cutaneous and canine visceral leishmaniases focus in Serra da Bodoquena, Brazil. Vet Parasitol. 2009; 160(1-2): 18-24. PMid:19062193. http://dx.doi. org/10.1016/j.vetpar.2008.10.090

Shaw SE, Day MJ, Birtles RJ, Breitschwerdt EB.Tick-borne infectious diseases of dogs. Trends Parasitol 2001; 17(2): 74-80. http://dx.doi. org/10.1016/S1471-4922(00)01856-0

Silva GC, Benitez AN, Girotto A, Taroda A, Vidotto MC, Garcia JL, et al. Occurrence of Ehrlichia canis and Anaplasma platys in household dogs from northern Parana. Rev Bras Parasitol Vet 2012; 21(4): 379-385. PMid:23207986. http://dx.doi.org/10.1590/ S1984-29612012005000009

Solano-Gallego L, Baneth G. Babesiosis in dogs and cats-expanding parasitological and clinical spectra. Vet Parasitol 2011; 181(1): 48-60. PMid:21571435. http://dx.doi.org/10.1016/j.vetpar.2011.04.023

Souza AI, Oliveira TMFS, Machado RZ, Camacho AA. Soroprevalência da infecção por Trypanosoma cruzi em cáes de uma área rural do Estado de Mato Grosso do Sul. Pesq Vet Bras 2009; 29(2): 150-152. http://dx.doi. org/10.1590/S0100-736X2009000200011

Spolidorio MG, Torres MM, Campos WN, Melo AL, Igarashi M, Amude AM, et al. Molecular detection of Hepatozoon canis and Babesia canis vogeli in domestic dogs from Cuiabá, Brazil. Rev Bras Parasitol Vet 2011; 20(3): 253-255. PMid:21961759. http://dx.doi.org/10.1590/ S1984-29612011000300015

Tanikawa A, Labruna MB, Costa A, Aguiar DM, Justiniano SV, Mendes RS, et al. Ehrlichia canis in dogs in a semiarid region of Northeastern Brazil: Serology, molecular detection and associated factors. Res Vet Sci 2013; 94(3): 474-477. PMid:23141416. http://dx.doi.org/10.1016/j. rvsc. 2012.10 .007

Trapp SM, Messick JB, Vidotto O, Jojima FS, De Morais HS. Babesia gibsoni genotype Asia in dogs from Brazil. Vet Parasitol 2006; 141(1-2):177180. PMid:16765518. http://dx.doi.org/10.1016/j.vetpar.2006.04.036

Unver A, Perez M, Orellana N, Huang H, Rikihisa Y. Molecular and antigenic comparison of Ehrlichia canis isolates from dogs, ticks, and a human in Venezuela. J Clin Microbiol 2001; 39(8): 2788-2793. PMid:11473993 PMCid:PMC88240. http://dx.doi.org/10.1128/ JCM.39.8.2788-2793.2001

Vexenat AC, Santana JM, Teixeira AR. Cross-reactivity of antibodies in human infections by the kinetoplastid protozoa Trypanosoma cruzi, Leishmania chagasi and Leishmania (Viannia) braziliensis. Rev Inst Med Trop S Paulo 1996; 38(3): 177-185. http://dx.doi.org/10.1590/S003646651996000300003

Vieira TSWJ, Vieira RFC, Nascimento DAG, Tamekuni K, Toledo RS, Chandrashekar R, et al. Serosurvey of tick-borne pathogens in dogs from urban and rural areas from Parana State, Brazil. Rev Bras Parasitol Vet 2013; 22(1): 104-109. http://dx.doi.org/10.1590/S198429612013000100019 